\title{
Veleszületett szemhéjcsüngés múttéti megoldása a szemhéjemelő izom kötőhártya felőli redőzésével
}

\author{
Antus Zsuzsanna dr. ${ }^{1}$ - Lukáts Olga dr. ${ }^{1}$ - Szalai Irén dr. ${ }^{1}$ \\ Nagy Zoltán Zsolt dr. ${ }^{1}$ - Szentmáry Nóra dr. ${ }^{1,2}$ \\ 'Semmelweis Egyetem, Általános Orvostudományi Kar, Szemészeti Klinika, Budapest \\ ${ }^{2}$ Dr. Rolf M. Schwiete Zentrum für Limbusstammzellforschung und Kongenitale Aniridie, \\ Universitätsklinikum des Saarlandes, Klinik für Augenheilkunde, Homburg/Saar, Germany
}

Bevezetés: Szemhéjcsüngésnek (ptosis vagy blepharoptosis) nevezzük azt az állapotot, amikor a felső szemhéj abnormálisan alacsony pozícióban van. A szemhéjcsüngésnek lehetnek veleszületett és szerzett formái.

Célkitüzés: Célunk volt bemutatni a szemhéjemelő izom (levator) - veleszületett szemhéjcsüngés korrekciója céljából végzett - kötőhártya felőli redőzésének eredményeit retrospektív módszerrel.

Módszer: 20 beteg 22 szemhéján végeztük el a mútétet (átlagéletkor: 19,4 \pm 9,9 év, férfi: 12 [60\%], nő: 8 [40\%]). Beválasztási kritérium volt a közepes (5-8 mm) vagy jó (9 mm felett) levatorfunkció. Kizártuk a korábban szemhéjkorrekciós műtéten átesett és a 3 hónapnál rövidebb követési idővel rendelkező betegeket. A mútét előtt megmértük a levatorfunkciót és a margó-reflex-távolságot. A mútét után megmértük a margó-reflex-távolságot, a szemhéjak magassága közti aszimmetria mértékét, és elemeztük a szemhéj posztoperatív kontúrját.

Eredmények: A preoperatív levatorfunkció $10,6 \pm 3,0 \mathrm{~mm}$, a preoperatív margó-reflex-távolság 1,8 $8 \pm 0,8 \mathrm{~mm}$ volt. A 7,8 \pm 7,2 hónap átlagos követési idő alatt a posztoperatív margó-reflex-távolság $3,2 \pm 0,8 \mathrm{~mm}$ volt. A preoperatív és a posztoperatív margó-reflex-távolság különbsége nem tért el szignifikánsan a sikeres és a sikertelen mútétek között $(\mathrm{p}=0,523)$. A szemhéjak magassága közti aszimmetria mértéke 3 betegnél haladta meg az $1 \mathrm{~mm}$-t. A szemhéj posztoperatív kontúrja minden esetben megfelelő volt. A mütét összességében 86,4\%-ban (19/22) volt sikeres. A helyi érzéstelenítésben és altatásban végzett mútétek közt nem találtunk szignifikáns különbséget a sikeresség tekintetében $(\mathrm{p}=0,227)$.

Következtetés: Tanulmányunk alapján az elvégzett mútéteink eredményessége a nemzetközi irodalomban közöltekhez hasonló volt. A veleszületett szemhéjcsüngés korrekciójára a kötőhártya felőli levatorredőzés megfelelő kezelési mód közepes vagy annál jobb levatorfunkció esetén.

Orv Hetil. 2021; 162(18): 705-711.

Kulcsszavak: veleszületett, szemhéjcsüngés, congenitalis, ptosis, kötôhártya

\section{Congenital ptosis repair using posterior approach levator plication}

Introduction: Droopy eyelid (ptosis or blepharoptosis) is defined through abnormally low upper eyelid position. Ptosis can be classified as congenital or acquired.

Objective: Our purpose was to report the results of posterior approach levator plication for congenital ptosis in a retrospective review.

Method: 22 eyelids of 20 patients were included in this study (age: $19.4 \pm 9.9$ years, male: 12 [60\%], female: 8 [40\%]). The inclusion criteria were moderate $(5-8 \mathrm{~mm}$ ) or good (more than $9 \mathrm{~mm}$ ) levator function. Patients with postoperative follow-up time shorter than 3 months and those who underwent previous eyelid surgery were excluded. The data collected included preoperative levator function and margin reflex distance, postoperative margin reflex distance, inter-eyelid height asymmetry and postoperative eyelid contour.

Results: Preoperative levator function was $10.6 \pm 3.0 \mathrm{~mm}$, preoperative margin reflex distance was $1.8 \pm 0.8 \mathrm{~mm}$. During $7.8 \pm 7.2$ months postoperative follow-up, postoperative margin reflex distance was $3.2 \pm 0.8 \mathrm{~mm}$. The difference between preoperative and postoperative margin reflex distance was not significant $(\mathrm{p}=0.523)$ in the group of successful operations compared with unsuccessful operations. Inter-eyelid height asymmetry was more than $1 \mathrm{~mm}$ in 3 cases. Satisfactory postoperative eyelid contour was achieved in all cases. Overall success rate was 86.4\% (19/22). Surgical success did not differ significantly between surgeries in local or general anaesthesia $(\mathrm{p}=0.227)$. 
Conclusion: Our study shows an overall success rate of the procedures comparable to those in international publications. Posterior approach levator plication for congenital ptosis with moderate or better levator function seems to be a suitable treatment method.

Keywords: inborn, droopy eyelid, congenital, ptosis, conjunctiva

Antus Zs, Lukáts O, Szalai I, Nagy ZZs, Szentmáry N. [Congenital ptosis repair using posterior approach levator plication]. Orv Hetil. 2021; 162(18): 705-711.

(Beérkezett: 2020. október 22.; elfogadva: 2020. november 26.)

Szemhéjcsüngésnek (ptosis vagy blepharoptosis) nevezzük azt az állapotot, amikor a felső szemhéj abnormálisan alacsony pozícióban van. Normális állapotban a felső szemhéj 1-2 mm-rel fedi a szaruhártya felső szélét. Szemhéjcsüngésról beszélünk, ha a felső szemhéj ennél lejjebb helyezkedik el [1]. A felső szemhéj alacsony pozíciója miatt a pupillát valamilyen mértékben takarhatja. A ptosis a súlyossága szerint lehet enyhe vagy kisfokú (2 mm-ig), mérsékelt (3 mm) és súlyos (4 mm vagy több). A szemhéjcsüngésnek lehetnek veleszületett és szerzett formái [2]. A veleszületett és a szerzett ptosis előfordulásában a nemek között és a különböző rasszokban nincs különbség. A congenitalis forma már születéskor jelen van, vagy az első életév folyamán manifesztálódik. Érintheti csak az egyik vagy mindkét szemet.

A veleszületett szemhéjcsüngés korai felismerése elengedhetetlen a szülészek, neonatológusok, háziorvosok, házi gyermekorvosok, szemészek, gyermekszemészek számára. Mivel a csüngő szemhéj eltakarhatja a látótengelyt, occlusiós, vagy más néven deprivatiós amblyopia (tompalátás) alakulhat ki $[3,4]$. A ptosishoz gyakran társuló fénytörési hibák kezelésével és az időben elvégzett, megfelelő típusú korrekciós mútéttel együttesen biztosítható a normális látásfejlődés, megelőzhető a tompalátás kialakulása, amely hatékonyan csak kisiskoláskor előtt kezelhető. Az amblyopia nemcsak occlusiós eredetü lehet, hanem a szemhéjcsüngéshez társuló kezeletlen fénytörési hibákból, astigmatismusból is adódhat [3]. A tompalátók akár funkcionálisan meg is vakulhatnak az érintett szemen. A tompalátás örökre meghatározza egy fiatal életét, korlátozza a pályaválasztást, ezáltal befolyásolja az életpályát [4]. A mütéti úton nem korrigált szemhéjcsüngés úgynevezett ocularis torticollist okozhat, amely kóros fejtartással, felfelé emelt állal jár. A kóros fejtartás a látás tengelyének szabaddá tétele céljából és a kétszemes együttlátás biztosítására alakul ki. Ez hosszú távon súlyos, az életminőséget jelentősen rontó nyak- és hátfájdalmat idéz elő. Hasonló esetben kisgyermekeknél megkésett motoros fejlődést figyeltek meg [5]. A korrekciós mütét elvégzése után a kóros fejtartás, a nyak- és hátfájdalom megszúnik, a gyermekek motoros fejlődése rendeződik. Bár a szemhéjcsüngés nem a leggyakoribb oka a fentieknek, mégis minden, hasonló panasszal és tünettel találkozó orvosnak gondolnia kell erre az eshetőségre
[5]. A congenitalis ptosis időben történő diagnosztizálásával, az esetleges társuló szemészeti vagy neurológiai betegségek felismerésével, a páciens megfelelő centrumba irányításával mindezek a súlyos következmények elkerülhetők és szerencsés esetben visszafordíthatók lennének.

Eredete szerint a ptosis lehet neurogen (a szemhéjemelő vagy a Müller-izom kóros beidegzése), myogen (magának a szemhéjemelő izomnak az abnormalitása vagy nem megfelelő fejlődése, ez utóbbi a „dystrophiás” típus), aponeuroticus (a szemhéjemelő izom aponeurosisának, vagy az aponeurosis és a tarsus összeköttetésének defektusa) és mechanikus (felső szemhéji és elülső felső szemüregi tumor vagy a felső kötőhártya-áthajlás összenövései, hegesedése). A szemhéjcsüngés előbb felsorolt formái különböző gyakorisággal minden életkorban előfordulhatnak, és lehetnek veleszületettek vagy szerzettek. A congenitalis „dystrophiás” és az involutiós eredetü aponeuroticus ptosis a leggyakoribb a klinikai gyakorlatban $[2,6]$.

Veleszületett „dystrophiás” szemhéjcsüngés esetén a levator izom változatos mértékü zsíros és fibrosus degeneratiója figyelhető meg. A levatorfunkció lehet normális (15-18 mm), jó (9-14 mm), közepes (5-8 mm), gyenge (4 $\mathrm{mm}$ és alatta), vagy teljesen hiányozhat. A ptosis lehet bármilyen fokú (enyhe, mérsékelt vagy súlyos). Előfordulhat önmagában, de társulhat a felső egyenes szemizom gyengeségével is $[2,6]$.

Tanulmányunkkal Blaskovics László professzor (18691938 ) előtt szeretnénk tisztelegni, aki az 1900-as években nemzetközileg is elterjedt, a kötőhártya felől végzett ptosiskorrekciós mütétek „atyjának” tekinthető [7]. Munkánk célja volt bemutatni a szemhéjemelő izom veleszületett szemhéjcsüngés korrekciója céljából végzett - kötőhártya felőli redőzésének technikáját és eredményeit retrospektív módszerrel.

\section{Módszer}

Tanulmányunk során veleszületett szemhéjcsüngés korrekciója céljából a kötőhártya felől végzett levator-előrehelyezés és -redőzés (ezután levatorredőzés) eredményeit vizsgáltuk retrospektív módszerrel. Kutatásunk elvégzéséhez a Semmelweis Egyetem Regionális, Intéz- 
ményi Tudományos és Kutatásetikai Bizottságának engedélyével rendelkezünk (SE RKEB szám: 79/2020.). A tanulmányt a Helsinki Deklaráció elveivel összhangban végeztük.

Tanulmányunkba 20, veleszületett szemhéjcsüngéssel rendelkező beteget ( 22 felső szemhéj) vontunk be, akik a kötőhártya felől végzett levatorredőzésen estek át (2014. április 1. és 2017. március 31. között) a Semmelweis Egyetem Szemészeti Klinikáján. 2 beteg kétoldali, 18 beteg egyoldali ptosisát korrigáltuk. 15 mútétet $(68,2 \%)$ végeztünk helyi érzéstelenítésben, 7 mútétet $(31,8 \%)$ altatásban. Megfelelő betegtájékoztatás után beleegyezó nyilatkozatot írt alá minden beteg, a 18 év alatti gyermekek esetében a szülő vagy a törvényes képviselő. Kizártuk a tanulmányból a korábban szemhéjkorrekciós mütéten átesett betegeket. Mütét előtt részletes anamnézist vettünk fel, általános szemészeti vizsgálatot végeztünk, az elülső és a hátsó szegmentumot is beleértve. A gyermekek gyermekszemészeti, orthopticai vizsgálaton estek át a mütétet megelőzően. Mindenkinél ellenőriztük a szemmozgásokat, a pupillákat és a pupillareakciókat. Vizsgáltuk a Bell-jelenséget, lagophthalmus, kóros fej- és álltartás meglétét, a könnyfilm minőségét, száraz szem gyanúja esetén a könnytermelést, az esetleges neuroophthalmologiai tüneteket. Megmértük a preoperatív margó-reflex-távolságot, a levatorfunkciót, a szemhéji redő magasságát. A mútét után a betegeket rendszerint 1 hét, 1 hónap és 3 hónap múlva ellenőriztük. Hosszabb követési idejü betegeink is voltak, de kizártuk a tanulmányból azokat, akiknél a követési idő 3 hónapnál rövidebb volt. A kontrollok alkalmával megmértük a posztoperatív margó-reflex-távolságot, vizsgáltuk a szemhéj kontúrját és a két szemhéj magassága közti szimmetriát. A sikeresség feltétele volt, hogy a posztoperatív margó-reflex-távolság $2 \mathrm{~mm}$ és 4,5 mm közé essen, a szemhéjak magassága közti aszimmetria mértéke ne haladja meg az $1 \mathrm{~mm}$-t (ne legyen túlkorrigálva az egyik szemhéj a másikhoz képest), és a szemhéj kontúrja megfelelő legyen egyenetlenség és kicsúcsosodás nélkül.

A statisztikai elemzést az SPSS Statistics 17.0 programmal (SPSS Inc., Chicago, IL, Amerikai Egyesült Államok) végeztük. Az elemszámot figyelembe véve nemparaméteres vizsgálatokat alkalmaztunk, nevezetesen a Kendall-féle tau-b-korrelációt, a Fisher-féle egzakt és a Mann-Whitney-féle U-tesztet.

\section{Mütéti technika}

Az aszepszis szabályainak megfelelő lemosás és izolálás után a mütét első lépéseként helyi csepp- és infiltrációs érzéstelenítést végeztünk. Az altatásban végzett beavatkozásoknál is alkalmaztunk kiegészítő csepp- és infiltrációs érzéstelenítést. A cseppérzéstelenítést Humacainnal (oxibuprokain-hidroklorid $4 \mathrm{mg} / \mathrm{ml}$, TEVA, Debrecen), az infiltrációs érzéstelenítést 2\% Lidocain-0,001\% Adrenalin (lidokain-hidroklorid/epinefrin $20 \mathrm{mg} / 0,01 \mathrm{mg} /$ ml oldatos injekció, EGIS, Budapest), valamint Naropin (ropivakain-hidroklorid-monohidrát $7,5 \mathrm{mg} / \mathrm{ml}$ oldatos injekció, AstraZeneca AB, Södertälje, Svédország) 1 : 1 arányú keverékével végeztük. A helyi érzéstelenítőt a felső szemhéji redő mentén és a praetarsalis régióba subcu$\tan (1 \mathrm{ml})$, valamint szemhéjkifordítást követően a tarsus feletti részen subconjunctivalisan $(0,5 \mathrm{ml})$ fecskendeztük be. A szemhéjszéli sulcus intermarginalisba 4/0-ás selyem (Ethicon, Somerville, NJ, Amerikai Egyesült Államok; Silk, fekete, hagyományos vágótü, $26 \mathrm{~mm}, 3 / 8$ kör, 45 cm, kód: W536H) eltartóvarratot helyeztünk, majd a szemhéjat Desmarres-kanál segítségével kifordítottuk. A conjunctiván óvatos diathermiát alkalmaztunk közvetlenül a tarsus felső széle felett és annak mentén az epithelialis sejtek eltávolítása céljából, a későbbi varratok behelyezési pontjain. Közvetlenül a tarsus felső széle felett és annak mentén kötőhártyametszést ejtettünk 15-ös szikével. A Müller-izmot és a conjunctivát egyben, összetett lebenyként választottuk le a „fehér vonal” azonosításáig, ami a levatoraponeurosisnak a hátsó határát képezi. Továbbhaladtunk a preparálással az aponeurosis hátsó felszíne és a conjunctiva között, amíg fel nem tártuk a levator izom hátsó felszínét. A levatoraponeurosis hátsó felszíne és a conjunctiva között gyakran találkozhatunk egy fibrosus, szorosan tapadó, vékony zsírszöveti réteggel, melyet postaponeuroticus zsírszövetnek nevezünk [8]. Ezután duplatûs, 5/0-ás Vicryl varratot (Ethicon, Coated Vicryl, polyglactin 910, festetlen, S-24, spatulatû́, 8 mm, l/4 kör, 45 cm, kód: W9753) helyeztünk a tarsus centrális csúcsával egybeeső vertikális vonal mentén a levator izom hátsó felszínébe az aponeurosis felett

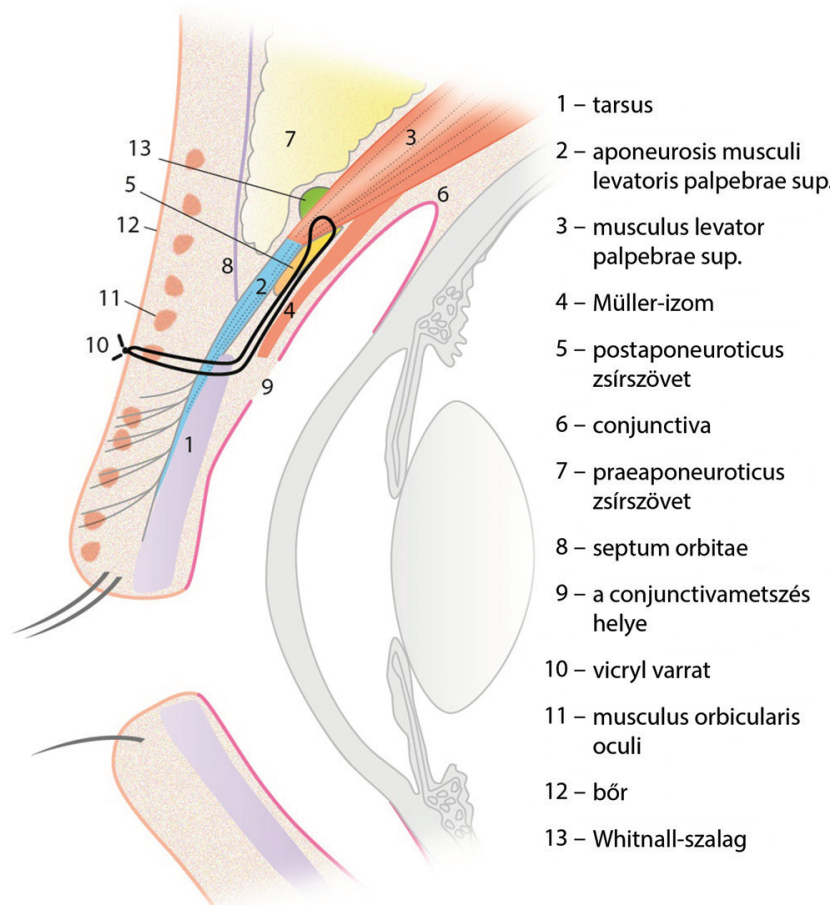

\begin{tabular}{l|l} 
1. ábra & A szemgolyó és a szemhéjak sagittalis metszete. A conjunctiva
\end{tabular} felól végzett levatorredőzés során a levatort a hátsó felszínébe helyezett duplatűs varrattal rögzítjük a tarsus felső részéhez, azon keresztülöltve, majd a bőrön megcsomózva 
kb. 1 mm-rel, azoknál a betegeknél, akiknek a levatorfunkciója 8 és $10 \mathrm{~mm}$ közé esett ( 9 beteg 11 szemhéja). Ha a levatorfunkció $8 \mathrm{~mm}$-nél rosszabb volt, az első varratot kissé magasabban helyeztük be a levator izomba, 3-4 mm-rel feljebb a fehér aponeurosis kezdeténél (2 beteg 2 szemhéja). Akiknél a levatorfunkció 10 mm vagy annál jobb volt, az első varratot a fehér aponeurosis felső széle és a levator találkozásánál helyeztük el $(9$ beteg 9 szemhéja).

A tüt kétszer öltöttük át a levatoron, figyelve arra, hogy az részvastagságú öltés legyen. Ezután a tarsus felső határa alatt, de attól $1 \mathrm{~mm}$-en belül a varrat mindkét végével átöltöttünk a tarsuson, és a bőrön keresztül jöttünk ki a szemhéji redő területén vagy alatta. Fontos, hogy mindkét varrattal ugyanazon a ponton lépjünk át a bőr felszínére, hogy lehetővé tegyük a megcsomózott varratvégek elbújtatását. Mielőtt megkötöttük az első varratpárt, egy második duplatűs varratot helyeztünk el
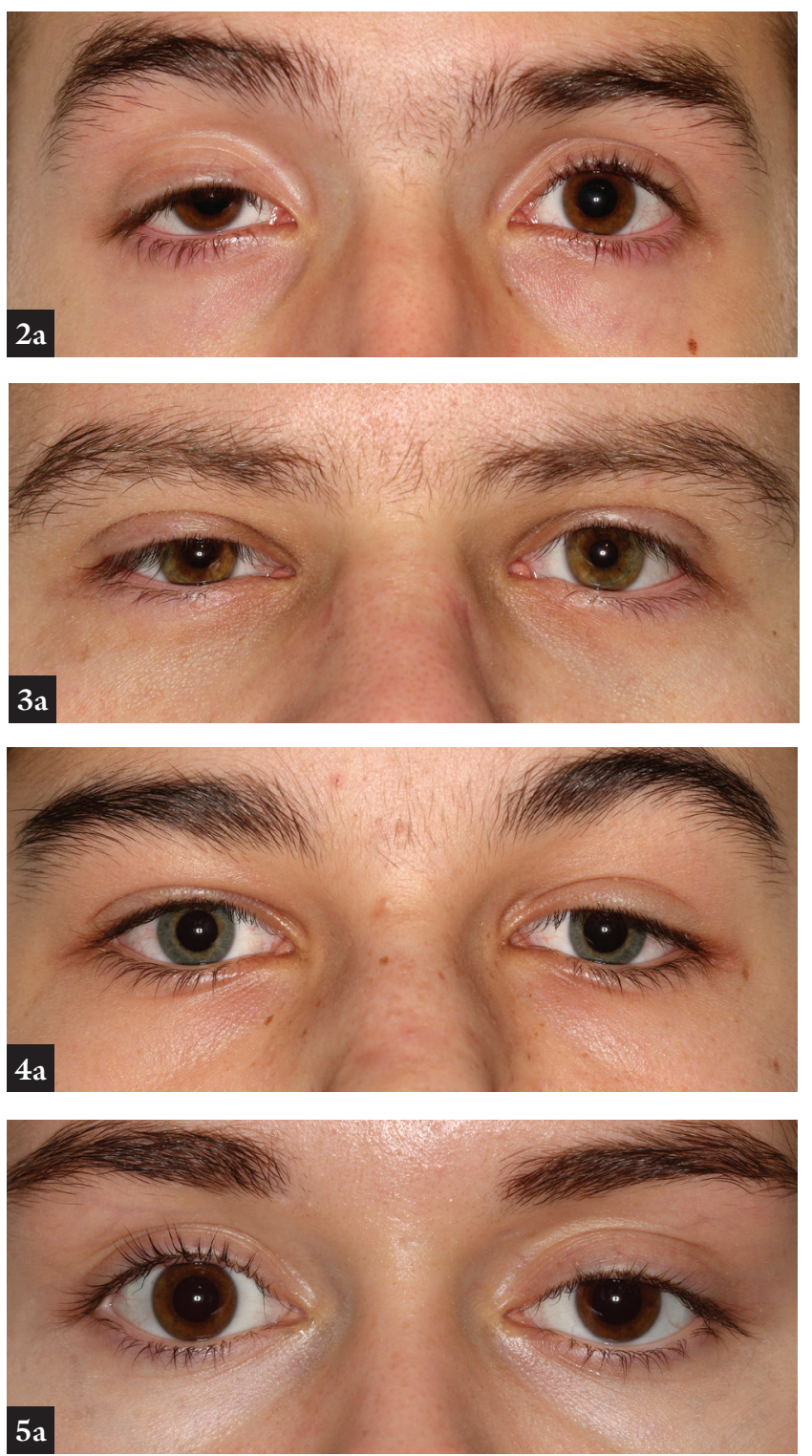

az elsőhöz hasonló módon, ugyanolyan magasságban a levator izomban, de az elsóhöz képest $2 \mathrm{~mm}$-en belül és medialisan. Ezután következett a tarsuson történő keresztülöltés, szintén az elsőhöz képest $2 \mathrm{~mm}$-en belül és medialisan, majd a bör felszínére való kiöltés, de ez már közvetlenül az első mellé és attól medialisan. Ezután mindkét varratpárt megkötöttük a bőrön. A felszívódó varratokat késóbb sem távolítottuk el a mútét után. A Müller-izmot és a conjunctivát hagytuk spontán gyógyulni, szöveteltávolítás és varratbehelyezés nem történt [9] (1. ábra).

\section{Eredmények}

Tanulmányunkban veleszületett szemhéjcsüngés miatt, kötőhártya felől végzett levatorredőzésen átesett 20 beteg 22 felső szemhéja szerepel. Az átlagéletkor 19,4 \pm 9,9 év (tartomány: 5-36 év), a férfiak száma 12 (60\%),
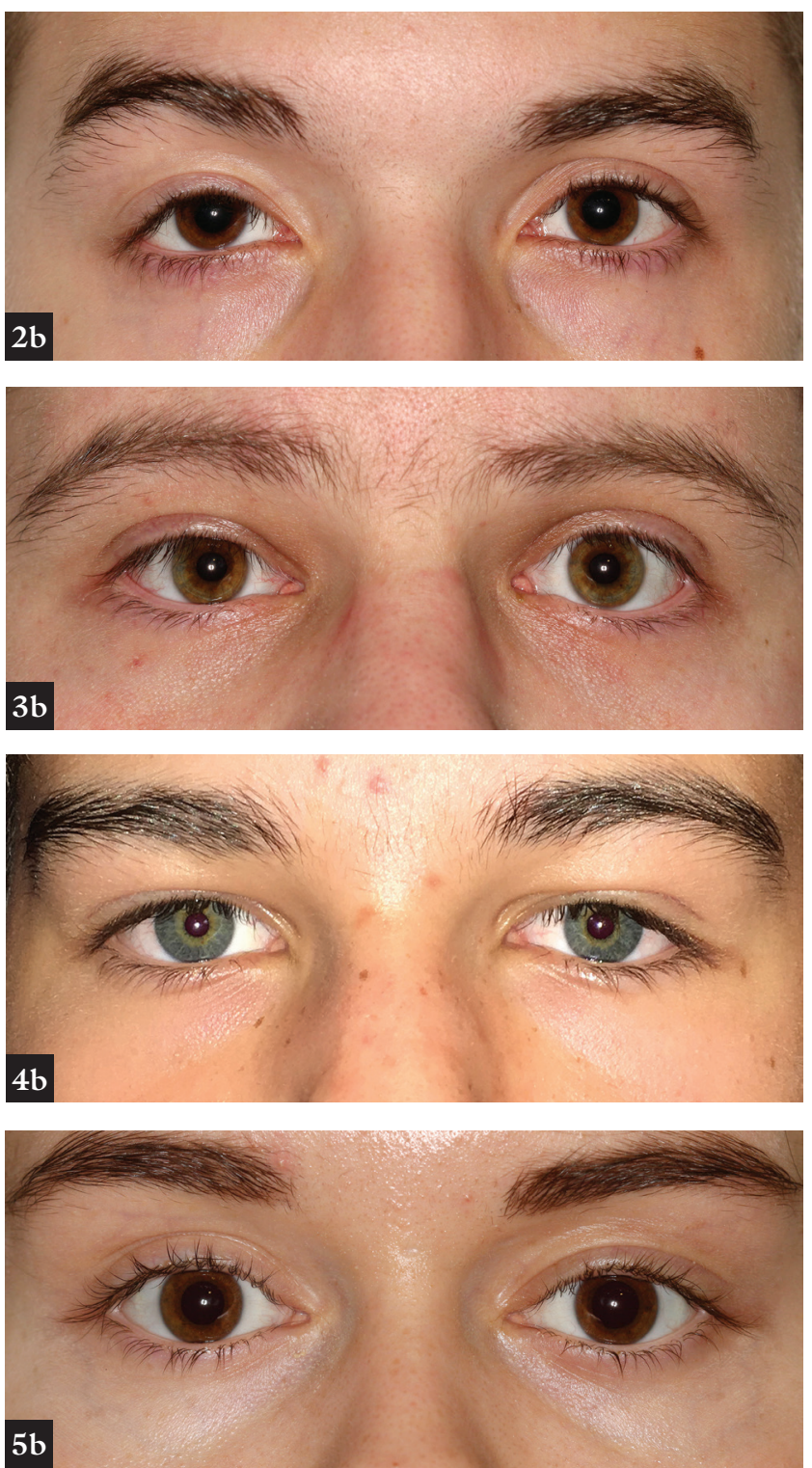

2-5. ábra | A conjunctiva felól végzett levatorredőzés. Preoperatív képek (a) és posztoperatív képek (b) 
a nőké $8(40 \%)$ volt. A ptosis minden betegnél születéstől kezdve fennállt az anamnézis alapján. 10 betegnél (50\%) találtunk valamilyen mértékű tompalátást. A Belljelenség mindenkinél megfelelő volt, lagophthalmus, könnyfilmeltérés vagy szárazszeműség senkinél nem igazolódott. 8 betegnél (40\%) találtunk kóros fej- és álltartást. Egy esetben volt valószínúsíthető Horner-szindróma, a többi esetben a ptosist „dystrophiás” eredetúnek tekintettük az anamnézis és az általunk elvégzett vizsgálatok alapján. Egyéb neuroophthalmologiai eltérést nem találtunk. 2 betegnél végeztünk kétoldali korrekciót egy ülésben. 15 mütétet végeztünk helyi érzéstelenítésben (68,2\%), 7 mütétet altatásban $(31,8 \%)$.

A preoperatív margó-reflex-távolság $1,8 \pm 0,8 \mathrm{~mm}$ (tartomány: 0-3,5 mm), a szemhéji redő preoperatív magassága $8,5 \pm 2,3 \mathrm{~mm}$ (tartomány: 5-15 mm), a levatorfunkció 10,6 $\pm 3,0 \mathrm{~mm}$ (tartomány: 7-16 mm) volt. $\mathrm{Az}$ átlagos követési idő 7,8 $\pm 7,2$ hónap (tartomány: 3-24,4 hónap), a posztoperatív margó-reflex-távolság 3,2 $\pm 0,8 \mathrm{~mm}$ (tartomány: $1-4 \mathrm{~mm}$ ) volt. A szemhéjak magassága közti aszimmetria mértéke 3 esetben (13,6\%) haladta meg az $1 \mathrm{~mm}$-t. A szemhéj posztoperatív kontúrja minden esetben megfelelő volt, egyenetlenség és kicsúcsosodás nélkül. A pre- és posztoperatív képeket a $2 a, b, 3 a, b, 4 a, b, 5 a, b$ ábrák mutatják be.

A preoperatív margó-reflex-távolság $(\mathrm{p}=0,046, \mathrm{t}=$ $0,349)$ és a levatorfunkció $(\mathrm{p}=0,008, \mathrm{t}=0,460)$ közepesen erôs pozitív korrelációt mutatott a posztoperatív margó-reflex-távolsággal. A preoperatív és a posztoperatív margó-reflex-távolság különbségében nem volt szignifikáns eltérés a sikeres és a sikertelen mütétek között ( $\mathrm{p}=0,523)$, a nemek között $(\mathrm{p}=0,324)$ és a helyi érzéstelenítésben és altatásban végzett mütétek között ( $\mathrm{p}=$ 0,112 ) sem. A mütét 86,4\%-ban (19 esetben a 22 esetből) volt sikeres az előre meghatározott feltételeket figyelembe véve. A helyi érzéstelenítésben végzett 15 mütét közül 14 (93,3\%), az altatásban végzett 7 mútétből 5 $(71,4 \%)$ volt sikeres. Az érzéstelenítés típusa nem befolyásolta a sikerességet, vagyis a helyi érzéstelenítésben és az altatásban végzett mútétek között nem volt szignifikáns eltérés a sikeresség tekintetében $(\mathrm{p}=0,227)$. A sikeres mútétek esetén szignifikánsan magasabb volt a levatorfunkció $(11,0 \pm 3,0 \mathrm{~mm})$ a sikertelen mütétekhez $(7,7 \pm 0,6 \mathrm{~mm})$ képest $(\mathrm{p}=0,049)$. A helyi érzéstelenítésben végzett mútétek esetén szignifikánsan magasabb volt a levatorfunkció $(11,9 \pm 2,8 \mathrm{~mm})$ és a posztoperatív margó-reflex-távolság $(3,5 \pm 0,6 \mathrm{~mm})$ az altatásban végzett mútétekhez képest $(7,7 \pm 0,5 \mathrm{~mm}$ és $2,4 \pm 0,8 \mathrm{~mm})$ $(\mathrm{p}=0,001$ és $\mathrm{p}=0,004)$. A nemek között nem volt szignifikáns eltérés a sikeresség tekintetében $(\mathrm{p}=0,642)$. 2 esetben a sikertelenséget alulkorrekció és a szemhéjak magassága közti, 1 mm-t meghaladó aszimmetria együttesen okozta. Közülük az egyiküknél reoperációt hajtottunk végre, a páciens azonban nem járt rendszeresen ellenőrzésre, így a végső kimenetelt nem ismerjük. A másik betegnél később frontalis suspensiót végeztünk altatásban, amelynek eredményeként a szemhéj a megfelelő po- zícióba került. Egy további páciensnél az altatásban végzett beavatkozást követően a posztoperatív margó-reflex-távolság megfelelően alakult, a két szemhéj magassága közti aszimmetria azonban meghaladta az elvárt mértéket. A mútét után a kóros fej- és álltartás minden esetben javulást mutatott. Mütéteink során 10 esetben $(45,5 \%)$ figyeltük meg a szemhéjemelő izom szemmel látható eltérését a normálistól, 3 esetben $(13,6 \%)$ zsíros degeneratiót is láttunk. Intra- és posztoperatív komplikáció nem lépett fel.

\section{Megbeszélés}

A congenitalis ptosis korrekciója a mai napig kihívást jelent a szemészek, szemhéjplasztikai sebészek számára. Mivel ez a kóros szemhéjállás többnyire gyermekeket és fiatal felnőtteket érint, a megfelelő funkció elérése mellett az esztétikai eredmény sem elhanyagolható szempont. Az általunk alkalmazott műtéti technikával, a kötőhártya felől végzett levatorredőzéssel a korábbi nemzetközi tapasztalatok alapján megfelelő szemhéjmagasság és szemhéjkontúr érhető el [9].

Az első feljegyzett, kötőhártya felól végzett ptosismútét Sir William Bowman brit szemész nevéhez füződik. 1857-ben veleszületett szemhéjcsüngés korrekciója céljából végzett transconjunctivalis levatorreszekciót és tarsectomiát $[10,11]$. A későbbiekben elterjedt, kötőhártya felól végzett, tarsectomiával kombinált levatorreszekció típusú ptosismútétek „atyjának” Blaskovics Lászlót (1869-1938) tekinthetjük, mütéti technikáját 1923-ban közölte [7]. Az aponeurosisnak a - Müllerizom-reszekciós mútétek sikerességének hátterében álló - előrébb helyeződése adja az alapját Collin kötőhártya felőli levator-előrehelyezéses technikájának és később a Malhotra által kifejlesztett, úgynevezett „white-line” előrehelyezéses mütétnek (fehér vonal: a kifordított szemhéjnál a tarsus felső széle menti kötőhártya-behatolásból húzást gyakorolva a Müller-izomra, az aponeurosis redőt képez, amely fehér vonalként jelenik meg) $[10,12,13]$. Collin levator-elörehelyezéses és Malhotra "fehér vonal” előrehelyezéses mútéte között az az alapvető különbség, hogy az utóbbi nem érinti az orbita septumát, és nincs benne tarsectomia, egyszerüen előrehelyezi az aponeurosis feltárt, hátsó felszínét. Ennek további módosítása a levatorredőzés (az angol nyelvü irodalomban 'levator plication' vagy 'levatorpexy'), amelyet congenitalis ptosis eseteiben alkalmaztak Malhotra és mtsai $[9,10,14]$.

Vizsgálatunk alapján a veleszületett szemhéjcsüngés korrekciója céljából, a kötőhártya felől végzett levatorredőzés sikeressége $(86,4 \%)$ a nemzetközi irodalomban (87\%) leírt adatokkal összevethető $[9,14]$. Al-Abbadi és mtsai 16, congenitalis ptosissal rendelkező beteg 19 szemhéján végeztek kötőhártya felőli levatorredőzést közepes és jó levatorfunkció esetén $87 \%$-os sikerrátával. A sikeresség feltétele volt a $2 \mathrm{~mm}$ és $4,5 \mathrm{~mm}$ közti posztoperatív margó-reflex-távolság, a megfelelő posztopera- 
tív szemhéjkontúr, és a két szemhéj magassága közti aszimmetria nem haladhatta meg az 1 mm-t [9]. Feldman és mtsai 16 beteg 18 szemhéján végeztek kötőhártya felőli levatorredőzést veleszületett szemhéjcsüngés esetén $87 \%$-os sikerrátával. 13 betegnek közepes és jó, 3 betegnek (4 szemhéj) gyenge ( $4 \mathrm{~mm}$ vagy annál rosszabb) volt a levatorfunkciója. A sikeresség feltételei megegyeztek az előző közleményben leírtakkal [14].

Tanulmányunkban közepes és jó levatorfunkcióval rendelkező betegek szerepeltek, esetszámunk kicsit magasabb volt ( 20 beteg 22 szemhéja) a korábban leírt közleményhez képest (16 beteg 19 szemhéja) [9]. 15 mütétet végeztünk helyi érzéstelenítésben a 14 év feletti betegcsoportban, 7 mütétet altatásban, szemben külföldi kollégáinkkal, akik minden mútétet altatásban hajtottak végre [9].

A mútét előnye, hogy nincs külső bőrseb, csak egy láthatatlan, belső heg marad a kötőhártyán. A kötőhártyasebet nem szükséges varrattal zárni, mivel a műtéti preparáláskor képzett lebeny magától visszatapad a helyére, így elkerülhető a varratok dörzsöléséből esetlegesen adódó szaruhártya-sérülés. A beavatkozás további előnye, hogy semmiféle szemhéjszövet nem kerül eltávolításra (conjuctiva, tarsus, Müller-izom, levator) más típusú, szövetek reszekcióján alapuló mütétekkel szemben. A mütét során kötőhártyametszésből a levator hátsó felszínét felkeressük, és az izmot előrébb helyezve rögzítjük a tarsushoz, azon keresztülöltve, majd a bőrön megcsomózva. A felszívódó varratok eltávolítása a későbbiekben sem szükséges.

A mütéti technika során előrefelé irányuló redő képződik a levatoron és az aponeurosison, valamint a levator előrébb helyezésével a praeaponeuroticus zsírszövet is előrébb helyeződik. Mindezek elősegítik a felső szemhéj praeseptalis redőjének teltebbé válását, így csökken az egyenes előretekintéskor a szemhéjszél és a felső szemhéji redő közti távolság (pretarsal show). Még az elvártnál kisebb margó-reflex-távolság esetén is esztétikailag elfogadhatóbb a betegek számára az eredmény a fentebb leírt távolság csökkenésével vagy a szimmetria javulásával. A szemhéjak szimmetriájának szempontjából sokkal jobban számít a csökkent „pretarsal show”, mint önmagában a felső szemhéj magassága [9].

Putterman és Fett 1986-ban 10 éves tanulmányuk eredményét közölték, melyben 19 kisfokú congenitalis ptosist (1,5-2,5 mm) is korrigáltak Müller-izom- és conjunctivareszekciós technikával. Az operált és az egészséges szemhéj magassága közti különbség minden esetben 1,5 mm-en belül volt. Az esetek 84\%-ában értek el 2,5 mm és $5 \mathrm{~mm}$ közti posztoperatív margó-reflex-távolságot [15]. Lake és mtsai 2003-ban nyitott technikával végeztek Müller-izom- és conjunctivareszekciót jó levatorfunkcióval (9-14 mm) rendelkező betegeknél. A tanulmányukban részt vevő pácienseik között 8 veleszületett szemhéjcsüngés szerepelt. 61 szemhéjat operáltak 92\%-os sikerrátával, bár nem határozták meg pontosan a sikeresség kritériumait. Az egyik sikertelen esetük conge- nitalis ptosis volt [16]. Bajaj és mtsai 2004-ben kötőhártya felől végzett levatoraponeurosis-plikációt és Whitnall-szalag-előrehelyezést írtak le 10 veleszületett szemhéjcsüngéses esetben. Az esetek $80 \%$-ában a korrigált szemhéjak és az egészséges szemhéjak magasságának különbsége $1 \mathrm{~mm}$-en belül volt [17]. Berlin és Vestal 58, veleszületett esetben végzett bőr felőli levatoraponeurosis-előrehelyezést 4,6 hónap átlagos követési idővel. A sikeresség $52 \%$ volt az elöre meghatározott feltételek alapján (margó-reflex-távolság $2 \mathrm{~mm}$ és 4,5 mm között, szemhéjak közti aszimmetria kisebb, mint $1 \mathrm{~mm}$ ) [18]. Cates és Tyers 74\%-os sikerrátát ért el 92 congenitalis, egyoldali esetben végzett elülső levatorreszekciónál, 6 hónapos követési idő után, 4 mm-nél jobb levatorfunkciójú betegeken. Sikeresnek tekintették a mütétet, ha az operált szemhéj magassága az egészségeshez képest 1 mm-nél kisebb mértékben tért el [19]. Krobn-Hansen és Haaskjold 2013-ban publikálták módosított elülső levatorreszekciós technikájukat és mútéti eredményeiket veleszületett szemhéjcsüngés esetén. A beavatkozás során tompán preparálnak a levatoraponeurosis és a septum orbitae közt. A septum orbitaet nem nyitják meg, így az a retroseptalis zsírszövettel (praeaponeuroticus zsírszövet) együtt érintetlen marad. $18 \mathrm{~mm}, 5 \mathrm{~mm}$ és annál jobb levatorfunkcióval rendelkező egyoldali ptosisos betegeket operáltak. A sikeresség feltétele az 1 mm-nél kisebb, szemhéjak közti magassági eltérés, valamint a 3 mm-nél nagyobb margó-reflex-távolság és a szemhéj kielégítő vagy jó kozmetikai megjelenése (normális kontúr, szimmetrikus szemhéji redők és szimmetrikus teltség) volt. A sikerráta $88 \%$ volt 6 hónap átlagos követési idő után [20]. 2020 júniusában Sagili és Ha írták le congenitalis ptosis korrekciójára elülső, bőr felól végzett 'levatorpexy' technikájukat, melyet 15 szemhéjon hajtottak végre 6 és $10 \mathrm{~mm}$ közötti levatorfunkciójú, súlyos fokú ptosissal rendelkező betegeken. A posztoperatív margó-reflex-távolság 3,2 mm (tartomány: 2-4 mm), az átlagos követési idő 14 hónap (tartomány: 2-48 hónap) volt [21].

A nemzetközi irodalomban több sikeres mütéti technika ismert a veleszületett szemhéjcsüngés korrekciójára. Tanulmányunkhoz hasonló levatorfunkciójú betegcsoport részvételével, hasonló beteg- és esetszámmal két nemzetközi közleményt találtunk a kötőhártya felől végzett levatorredőzésről, melyek eredményeivel tanulmányunk eredményei összevethetők, mütéteink sikerrátája ezekkel megegyező $[9,14]$. A két közlemény egyikében az összes [9], a másikban egy eset kivételével az összes mútétet altatásban végezték [14]. A nemzetközi irodalomban nem találtunk olyan publikációt, amelyben vizsgálták és összehasonlították volna egymással a helyi érzéstelenítésben és az altatásban végzett, kötőhártya felőli levatorredőzés kimenetelét, eredményességét veleszületett szemhéjcsüngés esetén.

Tanulmányunk korlátja a közepes távú követési idő. A hosszabb távú követési idő felfedheti a szemhéjcsüngés 
esetleges késői kiújulását, de tudomásunk szerint az adatgyüjtés befejezését követő időszakban sem jelentkezett beteg a fent említett panasszal.

\section{Következtetés}

Eredményeink alapján a helyi érzéstelenítésben és az altatásban végzett, kötőhártya felőli levatorredőzés egyaránt sikerrel végezhető veleszületett szemhéjcsüngéssel rendelkező betegeknél. Következtetésként elmondhatjuk, hogy a kötőhártya felől végzett, bőrmetszés nélküli, szöveteltávolítással nem járó levatorredőzés javasolható technika közepes és jó levatorfunkció mellett a congenitalis ptosis eseteiben helyi érzéstelenítésben és altatásban egyaránt.

Anyagi támogatás: A közlemény megírása, illetve a kapcsolódó kutatómunka anyagi támogatásban nem részesült.

Szerzői munkamegosztás: A. Zs.: A vizsgálat tervezése. A. Zs.: A mútétek elvégzése. A. Zs., L. O.: A műtéti eredmények feldolgozása, posztoperatív betegkövetés. A. Zs., Sz. N.: A kézirat megszövegezése és javítása. Sz. I.: Irodalomgyújtés. Sz. N., N. Z. Zs.: Kritikai revízió. A cikk végleges változatát valamennyi szerző elolvasta és jóváhagyta.

\section{Érdekeltségek: A szerzőknek nincsenek érdekeltségeik.}

\section{Köszönetnyilvánítás}

Köszönjük $d r$. Bodor Zoltán orvosi illusztrátornak a mútéti technikáról készített rajzát és Széles Éva klinikai fotográfusnak a képi anyag elkészítését és szerkesztését.

\section{Irodalom}

[1] Lukáts O. Ptosis - droopy eyelid. In: Lukáts O. (ed.) Abnorma position of eyelids in clinical practice and surgical correction. [Ptosis - szemhéjcsüngés. In: Lukáts O. (szerk.) Kóros szemhéjállások klinikuma és mútéti korrekciója.] Medicina Könyvkiadó, Budapest, 2013; pp. 15-29. [Hungarian]

[2] Kanski JJ. Ptosis. In: Edwards R. (ed.) Clinical ophthalmology: a systematic approach. Elsevier Butterworth-Heinemann, Philadelphia, PA, 2007; pp. 133-140.

[3] Knézy K. What do we know about amblyopia? State-of-the-art diagnosis and therapy. [Mit tudunk az amblyopiáról? (Korszerú diagnosztika és terápia).] Szemészet 2017; 154: 126-131. [Hungarian]

[4] Zajácz M. Selected cases of eyelid and orbit abnormalities and possibilities for correction. [Válogatott esetek a szemhéj és orbita elváltozásaiból és azok megoldási lehetőségeiről.] Orv Hetil. 2009; 150: 675-680. [Hungarian]
[5] Bohnsack BL, Bhatt R, Kahana A. Nonophthalmic symptoms secondary to ocular torticollis from severe blepharoptosis: an underappreciated but treatable condition. Ophthalmic Plast Reconstr Surg. 2012; 28: e36-e39.

[6] Leatherbarrow B. Blepharoptosis. In: Leatherbarrow B. Oculoplastic surgery. 2nd edn. Informa Healthcare, London, 2011; pp. 136-176.

[7] Blaskovics L. Operations for ptosis. In: Blaskovics L. (ed.) Surgical techniques in ophthalmology. [Mútétek szemhéjcsüngés ellen. In: Blaskovics L. (szerk.) Szemészeti mütéttan.] Királyi Magyar Egyetemi Nyomda, Budapest, 1936; pp. 138-145. [Hungarian]

[8] Malhotra R, Mahadevan V, Leatherbarrow B, et al. The post-levator aponeurosis fat pad. Ophthalmic Plast Reconstr Surg. 2015; 31: 313-317.

[9] Al-Abbadi Z, Sagili S, Malhotra R. Outcomes of posterior-approach 'levatorpexy' in congenital ptosis repair. $\mathrm{Br} \mathrm{J}$ Ophthalmol. 2014; 98: 1686-1690.

[10] Ullrich K, Malhotra R. How far we have come: a review of the evolution of posterior approach ptosis surgery. Clin Exp Ophthalmol. 2019; 47: 1082-1087.

[11] Bowman W. Report of a chief operation performed at the Royal London Ophthalmic Hospital for the quarter ending 25th of September 1857. R Lond Ophthalmic Hosp Rep. 1859; 34: 1857-1859.

[12] Patel V, Salam A, Malhotra R. Posterior approach white line advancement ptosis repair: the evolving posterior approach to ptosis surgery. Br J Ophthalmol. 2010; 94: 1513-1518.

[13] Antus Z, Salam A, Horvath E, et al. Outcomes for severe aponeurotic ptosis using posterior approach white-line advancement ptosis surgery. Eye (Lond). 2018; 32: 81-86.

[14] Feldman I, Brusasco L, Malhotra R. Improving outcomes of posterior approach levatorpexy for congenital ptosis with reduced levator function. Ophthalmic Plast Reconstr Surg. 2018; 34: 460-462.

[15] Putterman AM, Fett DR. Müller's muscle in the treatment of upper eyelid ptosis: a ten-year study. Ophthalmic Surg. 1986; 17: 354-360.

[16] Lake S, Mohammad-Ali FH, Khooshabeh R. Open sky Müller's muscle-conjunctiva resection for ptosis surgery. Eye (Lond). 2003; 17: 1008-1012.

[17] Bajaj M, Pushker N, Mahindrakar A, et al. Advancement of Whitnall's ligament via the conjunctival approach for correction of congenital ptosis. Orbit 2004; 23: 153-159.

[18] Berlin AJ, Vestal KP. Levator aponeurosis surgery. A retrospective review. Ophthalmology 1989; 96: 1033-1036; discussion 1037.

[19] Cates CA, Tyers AG. Outcomes of anterior levator resection in congenital blepharoptosis. Eye (Lond). 2001; 15: 770-773.

[20] Krohn-Hansen D, Haaskjold E. A modified technique for levator resection in congenital ptosis. J Plast Surg Hand Surg. 2013; 47: 243-247.

[21] Sagili S, Ha J. Anterior approach levatorpexy for correction of congenital ptosis. Can J Ophthalmol. 2020; 55: 274-275.

(Antus Zsuzsanna dr., Budapest, Mária utca 39., 1085 e-mail: zsuzsanna.antus@gmail.com)

A cikk a Creative Commons Attribution 4.0 International License (https://creativecommons.org/licenses/by/4.0/) feltételei szerint publikált Open Access közlemény, melynek szellemében a cikk bármilyen médiumban szabadon felhasználható, megosztható és újraközölhető, feltéve, hogy az eredeti szerző és a közlés helye, illetve a CC License linkje és az esetlegesen végrehajtott módosítások feltüntetésre kerülnek. (SID_1) 